\title{
A Study of the Performance of PEMFC Hybrid Vehicle Using ADVISOR
}

\author{
Jingming Liang, Zefeng Wu \\ Department of Automotive Engineering, Guangdong Polytechnic Institute, Guangzhou, 510091, China
}

\begin{abstract}
This study investigates the configuration and optimization of an energy system for Polymeric electrolyte membrane fuel cell (PEMFC) based hybrid vehicle. The energy system determines the fuel economy and dynamic performance of the vehicle. Hence, this investigation stresses the optimal energy distribution for the three power sources, namely the fuel cell, battery and super-capacitor. In particular, an optimal energy distribution control strategy is undertaken in the auxiliary energy provider comprising a battery and super-capacitor, which can enhance the dynamic performance of the vehicle and prolong the life of its components. Advanced vehicle simulator (ADVISOR) is used in this research to determine an optimal energy distribution control strategy and achieves a good estimate of the performance of the PEMFC hybrid vehicle, saving time and cost.
\end{abstract}

Keywords-ADVISOR; PEMFC; vehicle; hybrid.

\section{INTRODUCTION}

Since petroleum supplies will be exhausted in the near future, new energy sources should be exploited to drive vehicle. Hydrogen is abundant and is used to power the PEMFC based hybrid vehicle with clean emissions. Thus, while the hybrid vehicle is developed, whose cost of research and using is so high that its development is hindered. To reduce the research costs for the PEMFC hybrid vehicle, a variety of computer simulation software is used, including ADVISOR.

This study is based on ADVISOR [1], which needs to be modified to obtain a better simulation result as for some vehicle models. The task is to improve and optimize the energy system to procure a new model.

\section{VEHICLE CONTROL STRATEGY}

The three main configurations for hybrid vehicle are series, parallel and hybrid configurations. Previous studies have elaborated on the advantages and disadvantages of these configurations [2, 3]. However, most of the fuel cell hybrid vehicles adopt the series configuration in a simple structural form. Consequently, this study applied the series structure [4]. The energy system is composed of a PEMFC stack using hydrogen and air, a lead-acid battery pack and a super-capacitor bank.

There are studies on control strategies for PEMFC hybrid vehicle, for instance, the fuzzy power control $[5,6]$, the neural network based algorithm, and power balance control [7]. In these systems, when the PEMFC hybrid vehicle is in traction and accelerating, the PEMC stack, battery pack and super-capacitor bank supply energy simultaneously. When the vehicle is braking, the battery pack and super-capacitor bank are recharged according to the battery state of charge (SOC) and the capacitor state of charge (CSOC). The whole energy system, in accordance with the control strategies, satisfies the power requirements of the vehicle. In studies [5, 6], when the fuel cell stack is insufficient, the supercapacitor supplies the necessary power. If the supercapacitor cannot provide sufficient energy either, the battery will supplement it. In this study, the auxiliary energy system control strategy is that its required energy will be provided proportionally by the battery and the super-capacitor simultaneously. This strategy should be able to protect the super-capacitor when the inertial factor makes the capacitor discharge too much. The CSOC then drops too fast and can damage the capacitor. Therefore, the proportion of energy from the super-capacitor and the battery should be optimized, and be restricted by the CSOC and SOC. This control strategy shows in Fig.1 (cs4), Fig. 2.

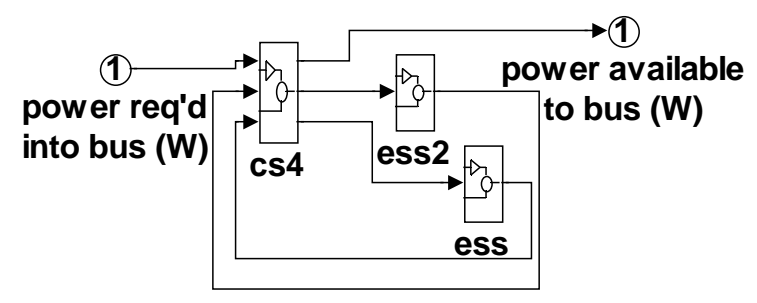

Figure 1. Dual ESS block diagram

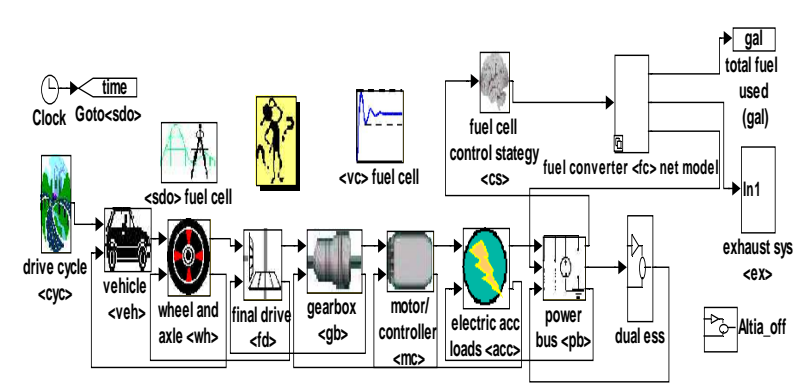

Figure 2. ADVISOR block diagram

\section{SIMULATION MODEL}

A. Vehicle modle

The vehicle model is rebuilt with the aim of a gasoline vehicle in China. Its mass is lighter than the gasoline vehicle, 
but its power is virtually equivalent. The specific parameters are given in Table I.

In this paper, the selection of the energy system is determined by the power demand of the vehicle. Pm1 is the power the vehicle needs to operate with a maximum speed of $130 \mathrm{~km} / \mathrm{h}$ as given in Equation (1). Pm2 is the power when the vehicle operates at an average speed of $25 \mathrm{~km} / \mathrm{h}$ with a slope of $15^{\circ}$ as shown in Equation (2). The vehicle power demand can be calculated by comparing the two values and choosing the larger one.

$$
\begin{gathered}
P_{m 1}=\frac{1}{3600 \cdot \eta_{t}}\left(m \cdot g \cdot f+\frac{C_{d} \cdot A \cdot u_{\max }{ }^{2}}{21.15}\right) u_{\max }, \\
P_{m 2}=\frac{1}{3600 \cdot \eta_{t}}\left(m \cdot g \cdot \sin \alpha+m \cdot g \cdot f \cdot \cos \alpha+\frac{C_{d} \cdot A \cdot u^{2}}{21.15}\right) \mu,
\end{gathered}
$$

Where $\eta \mathrm{t}$ is 0.9 -motor efficiency and Table 1 lists the remaining parameters.

TABLE I. VEHICLE CONFIGURATION

\begin{tabular}{|l|l|l|l|}
\hline Parameters & value & Parameters & value \\
\hline $\begin{array}{l}\text { Coefficient of } \\
\text { aerodynamic drag }\end{array}$ & 0.3 & $\begin{array}{l}\text { Fraction of vehicle } \\
\text { weight on front axle }\end{array}$ & 0.6 \\
\hline Frontal area $\left(\mathrm{m}^{2}\right)$ & 2 & $\begin{array}{l}\text { Vehicle wheelbase } \\
(\mathrm{m})\end{array}$ & 2.34 \\
\hline $\begin{array}{l}\text { Rolling resistance } \\
\text { coefficient }\end{array}$ & 0.01 & cargo mass $(\mathrm{kg})$ & 136 \\
\hline $\begin{array}{l}\text { Rolling radius of tire } \\
(\mathrm{m})\end{array}$ & 0.232 & Max. mass $(\mathrm{kg})$ & 1163 \\
\hline
\end{tabular}

After calculation, the required power is determined to be $49.2 \mathrm{~kW}$. To facilitate the simulation, a Honda $49 \mathrm{~kW}$ (continuous), permanent magnet motor is chosen.

\section{B. Energy system model}

The whole energy system includes the PEMFC stack, the battery pack and the super-capacitor bank. The power they supply should meet the maximum requirements of the motor. It is expressed in Equation 3. According to the operation conditions of the vehicle and to optimize the energy power distribution in ADVISOR, the required energy distribution was found to be Pfc_ava $=25 \mathrm{~kW}$, Pba_ava $=20 \mathrm{~kW}$ and the rest of the power was supplied by the super-capacitor, which is described by:

$$
P_{\text {req }}=P_{f_{c_{-} a v a}}+P_{u c_{-} a v a}+P_{b a_{-} a v a}
$$

Where Pfc ava, Pba ava and $\mathrm{Pba}$ ava, is power available from fuel cell stack, battery pack and supercapacitor.

1) Fuel cell model

The fuel cell is the device that converts the fuel (hydrogen) into electrical energy for the drive train. In this article [8] on the formation of fuel cell potential, potential polarization loss and the efficiency of fuel cells have introduced them in detail. The specific parameters are presented in Table 2 . The fuel cell is the main energy source for the vehicle. While the vehicle operates in traction, it provides the energy, simultaneously charging the battery and the super capacitor when the SOC and CSOC drop below a certain low value.

The fuel consumption of the PEMFC stack is a vital index for estimating the stack efficiency, and is also the target of the optimization process. The aim of this study is to make the fuel cell operate in an efficient area that will improve the vehicle economy. The control system monitors the hydrogen supply to provide the appropriate fuel for the fuel cell stack. The calculation equation can be described as follows:

$$
E_{\text {in_stack }}=\frac{1}{1000} * E_{\text {gal }} * \int_{\text {cycle }} q(t) d t \mathrm{~kJ},
$$

Where Egal represents the energy that each gallon of hydrogen contains, the equation is

\begin{tabular}{|c|c|c|c|}
\hline Parameters & value & Parameters & value \\
\hline \multicolumn{4}{|l|}{ PEMFC stack parameters } \\
\hline Active area per cell $\left(\mathrm{m}^{\wedge} 2\right)$ & 0.0769 & Stack mass $(\mathrm{kg})$ & 129 \\
\hline Number of cells & 73 & Stack max. power & 25 \\
\hline $\begin{array}{l}\text { Cold water temperature } \\
\left({ }^{\circ} \mathrm{C}\right)\end{array}$ & 20 & $\begin{array}{l}\text { Stack working } \\
\text { temperature }\left({ }^{\circ} \mathrm{C}\right)\end{array}$ & 80 \\
\hline Accessory load (W) & 700 & & \\
\hline \multicolumn{4}{|l|}{ Parameters of batteries [9] } \\
\hline Min_volts（v) & 10.1 & $\begin{array}{l}\text { Power } \\
\text { densities }(\mathrm{W} / \mathrm{kg})\end{array}$ & 160 \\
\hline Max_volts（v） & 14.85 & $\begin{array}{l}\text { Power } \\
\text { densities }(\mathrm{Wh} / \mathrm{kg})\end{array}$ & 13.3 \\
\hline Number of modules & 21 & Capacity(Ah) & 7.5 \\
\hline \multicolumn{4}{|c|}{ Super-capacitor specifications [10] } \\
\hline Module_mass(kg) & 0.71 & Current(rated)( A) & 625 \\
\hline Power density(W/kg) & 1838 & $\begin{array}{l}\text { Energy } \\
\text { density }(\mathrm{Wh} / \mathrm{kg})\end{array}$ & 7 \\
\hline Module_num(CAP_NUM) & 60 & Storaged energy $(\mathrm{J})$ & 8400 \\
\hline Min_volts(V) & 0.01 & Cap_lo_soc & 0.4 \\
\hline $\operatorname{Max} \_\operatorname{volts}(V)$ & 2.7 & Cap_hi_soc & 0.8 \\
\hline
\end{tabular}

$$
E_{\text {gal }}=3.785 * Q_{L} * \rho \mathrm{J} / \mathrm{gal} \text {. }
$$

TABLE II. ENERGY SYSTEM PARAMETERS

2) Battery model

The battery is superior in terms of high energy density and a correspondingly low power density in relation to the super-capacitor. The battery pack supplies most of the auxiliary power. To prolong the lifetime of the battery and enable it to supply sufficient power, the SOC is an important parameter. Equation 6 is used to calculate the SOC of the battery, which is a factor used to estimate the number of batteries, can be written as follows:

$$
S O C=S O C_{i n i t}-\frac{i \cdot t}{C_{\max }},
$$

Where $\mathrm{i}$ is the instantaneous current, $\mathrm{t}$ is the time and Cmax is the maximum capacitor size. The parameters of the battery are given in Table 2 .

\section{3) Super-capacitor model}

A super-capacitor is used in the vehicle configuration because of its high specific power density and its ability to 
accept a full recharge in a very short time, which improves the vehicle's efficiency and energy economy [11]. The use of a super-capacitor is especially beneficial if braking energy has to be recovered. The simulated super-capacitor is the Maxwell PC2500 Ultra-capacitor. The parameters of the super-capacitor are given in Table II.

\section{RESUlTS AND Discussion}

The simulation analysis of the vehicle's performance is based upon the above research. According to Fig. 3, when CAP NUM $=45$, the minimum CSOC rapidly reduces to below cap_lo_soc $=0.5$, which is not beneficial for the supercapacitor's life, but can be quickly recharged. When reaching CAP NUM $=60,65$, the minimum CSOC is close to cap_lo_soc, which results in better power performance and the $\overline{\mathrm{CSO}} \overline{\mathrm{C}}$ variable rate is moderate.

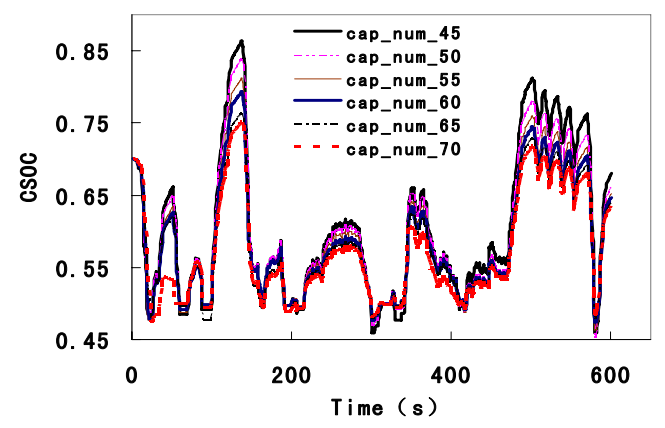

Figure 3. Super-capacitor number vs.CSOC in US06

Fig. 4 shows the grade and acceleration performance of the vehicle. When the value of the capacitor was increased, the grade capability of the vehicle fell, while the acceleration time from 0 to $100 \mathrm{~km} / \mathrm{h}$ increased, because there was a significant increase in the overall mass of the vehicle. According to the results shown in Fig. 3 and Fig. 4, we chose CAP_NUM=60, as a compromise by neither making the $\mathrm{CSOC}^{-}$surge by using $\mathrm{CAP} \mathrm{NUM}=45 \sim 55$, nor increasing the weight of vehicle by using CAP_NUM=70.

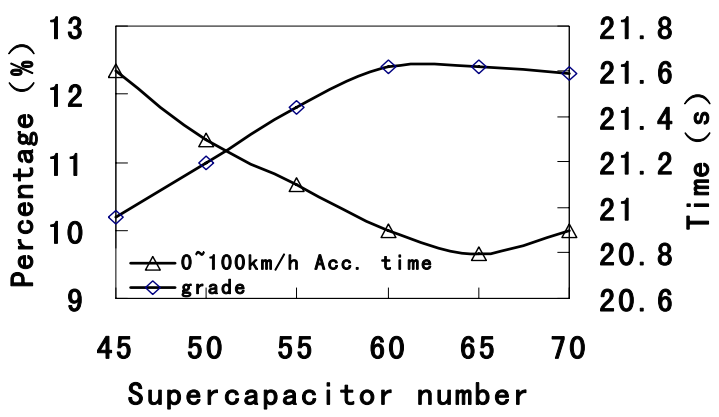

Figure 4. Super-capacitor number vs. vehicle performance

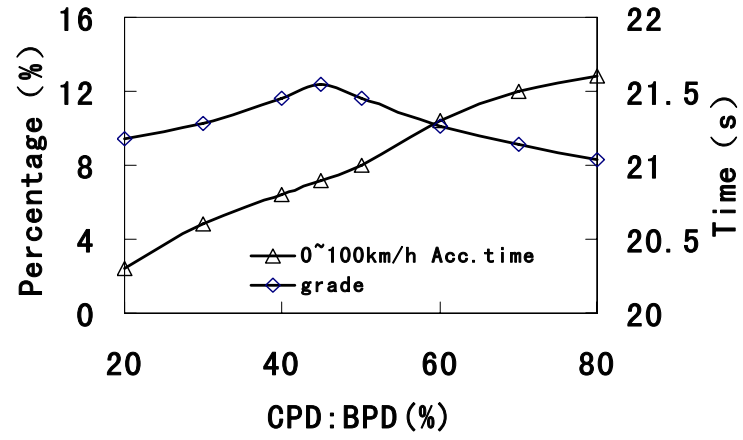

Figure 5. (CPD: BPD) vs. vehicle performance

Fig. 5 shows how the different ratio of super-capacity power demand (CPD) and battery power demand (BPD) affects the dynamic performance of the vehicle. The larger the ratio, the acceleration time is long to $0 \sim 100 \mathrm{~km} / \mathrm{h}$. This is because the super capacitor's role is to enhance the peak power, but the energy density is low, and it cannot supply adequate energy for long. From the grade curve, there exists an optimal grade value for the vehicle. It has a better climbing ability if the CPD: BPD is at $40 \% \sim 50 \%$. Hence, optimizing the auxiliary energy system can improve the vehicle's performance.

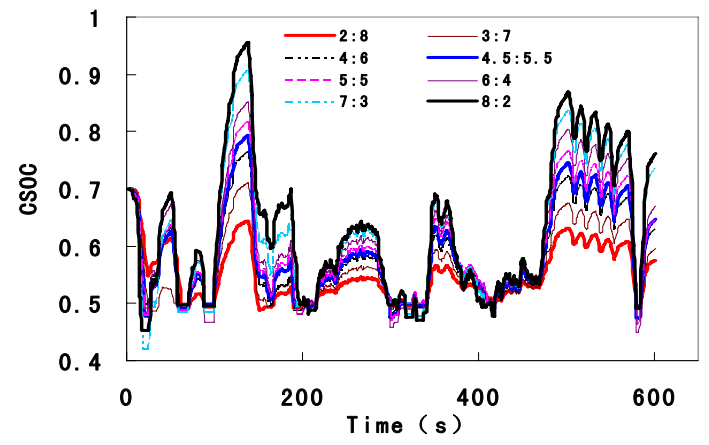

Figure 6. CSOC vs. (CPD: BPD) in the US06

Fig. 6 shows that the CSOC changes with different CPD: BPD in the US06. It shows a rapid fluctuation for the CSOC when the super-capacitor provides all the auxiliary energy. From this curve CPD: $\mathrm{BPD}=8: 2$, the

CSOC fluctuates between $0.45 \sim 0.96$ but it should remain between $0.4 \sim 0.8$ according to the control strategy. The restriction has already been exceeded. Because Puc req is much greater than Puc ava, the super-capacitor is not able to provide adequate power, and the battery pack responds slowly. For another curve CPD: $\mathrm{BPD}=2: 8$, the CSOC changes between $0.5 \sim 0.65$ most of the time. It shows the low efficiency of the super-capacitor. The curve CPD: BPD $=4.5: 5.5$ shows that it provides the optimum performance of the super-capacitor. 


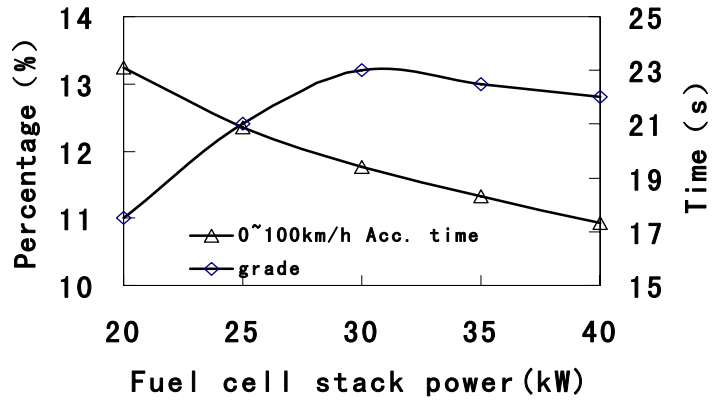

Figure 7. Fuel cell stack power vs. vehicle performance

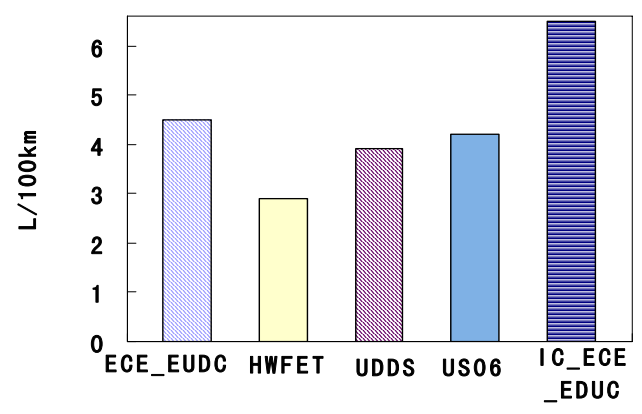

Figure 8. Different drive cycle vs. fuel consume

The optimization result of the fuel cell stack power is shown as Fig. 7, which shows that the acceleration time decreases with increasing fuel cell stack power for an acceleration time curve corresponding to $0 \sim 100 \mathrm{~km} / \mathrm{h}$. In terms of the grade curve, when stack power is about $30 \mathrm{~kW}$, the vehicle has maximum grade capability. This is because when increasing the stack power, both the stack mass and the vehicle grade resistance increase. Therefore, a stack power of $25 \mathrm{~kW}$ was chosen. The dynamic performance can now satisfy the operation needs of a city vehicle and save costs.

In order to verify the fuel economy of the stimulated vehicle, we selected four drive cycles that comprised ECE EUDC, HWFET, UDDS and US06 for test purposes. The test result is shown in Fig. 8. The HWFET gave the lowest fuel consumption, achieving $2.9 \mathrm{~L} / 100 \mathrm{~km}$, while the ECE_EUDC had the highest fuel consumption, reaching 4.5 $\mathrm{L} / 10 \overline{0} \mathrm{~km}$. However, its fuel consumption was lower than that of the reference IC ECE_EUDC, which reached 6.5 $\mathrm{L} / 100 \mathrm{~km}$, therefore, it had better economy.

\section{V.CONCLUSIONS}

Data gained from simulation analysis is compared with real vehicle one. Three points of view are concluded:

1) Based on the current vehicle conditions, 60 supercapacities and 21 batteries pack are applied, matching the stack of $25 \mathrm{~kW}$, the power system can work well and protect the super-capacities.

2) Energy control strategy, which uses the output power with batteries of 4.5 compared with the super capacities of 5.5, not only it can improve the vehicle system dynamics and its economy, but also prolong the vehicle lifespan, saving cost.

3) The simulation has its limitation. In the future, it is a necessity to carry out the real vehicle matching test to make the simulation more effective.

\section{REFERENCES}

[1] A.Brooker, K.Haraldsson, T.Hendricks, V. Johnson, K. Kelly, and B. Kramer, ADVISOR Documentation (Version 2002) : National Renewable Energy Lab., Apr. 30, 2002.

[2] Same, Adam, et al. "A study on optimization of hybrid drive train using Advanced Vehicle Simulator (ADVISOR)." Journal of Power Sources 195.19 (2010): 6954-6963.

[3] Gao D, Jin Z, Lu Q. Energy management strategy based on fuzzy logic for a fuel cell hybrid bus[J]. Journal of Power Sources, 2008, 185(1): 311-317.

[4] Jiang-Wen $\mathrm{Xu}$ and Liang Zheng .Simulation and Analysis of Series Hybrid Electric Vehicle (SHEV) based on ADVISOR. 2010 International Conference on Measuring Technology and Mechatronics Automation.

[5] Li C Y, Liu G P. Optimal fuzzy power control and management of fuel cell/battery hybrid vehicles [J]. Journal of power sources, 2009, 192(2): 525-533.

[6] Majdi L, Ghaffari A, Fatehi N. Control strategy in hybrid electric vehicle using fuzzy logic controller[C]. Robotics and Biomimetics (ROBIO), 2009 IEEE International Conference on. IEEE, 2009: 842847.

[7] Yun Haitao, Zhao Yulan, Sun Zechang, Wan Gangb .Model-based power control strategy development of a fuel cell hybrid vehicle. Journal of Power Sources 2008; 180:821-829.

[8] Hosseinzadeh E, Rokni M, Advani S G, et al. Performance simulation and analysis of a fuel cell/battery hybrid forklift truck [J]. International Journal of Hydrogen Energy, 2013, 38(11): 4241-4249.

[9] http://www.digikey.cn/Web\%20Export/Supplier\%20Content/Enersys _842/PDF/Enersys_XP_EP_Manual.pdf?redirected=1

[10] Electric Double Layer Capacitor: BOOSTCAP_ Ultracapacitor [Online]. <http://www.maxwell.com/pdf/uc/datasheets /PC2500.pdf>; 2005.

[11] Thounthong P, Chunkag V, Sethakul P, et al. Energy management of fuel cell/solar cell/supercapacitor hybrid power source $[\mathrm{J}]$. Journal of Power Sources, 2011, 196(1): 313-324. 